\title{
Spatial and temporal changes in macrobenthic communities in the Amazon coastal zone (Guajará Estuary, Brazil) caused by discharge of urban effluents
}

\author{
DAIANE AVIZ, IVANA LIA RODRIGUES DE CARVALHO \\ and JOSÉ SOUTO ROSA FILHO \\ Laboratório de Oceanografia Biológica, Instituto de Geociências, Universidade Federal do Pará, Rua Augusto Correa, s/n. \\ Guamá, Belém, Pará, Brasil. CEP: 66.075-110. E-mail: daianeaviz@ufpa.br
}

\begin{abstract}
SUMMARY: Spatial and temporal changes in the structure of soft-bottom macrobenthic communities caused by discharges of urban wastewater were studied in the Guajará Estuary, Amazon coastal zone, Brazil. Samples were taken during the dry and rainy seasons at five sites close to wastewater sources (impacted) and two sites further away from effluent discharges (non-impacted). Samples were collected using a Petersen grab $(20 \times 20 \times 20 \mathrm{~cm})$ and passed through a $0.3 \mathrm{~mm}$ mesh screen. At each site, several parameters were determined in order to characterize the water ( $\mathrm{pH}, \mathrm{QOD}$ and $\mathrm{NH}_{4}$ ) and sediment (mean grain size diameter, $\% \mathrm{OM}$ and heavy metals). The benthic fauna was composed of 22 taxa dominated by polychaetes and oligochaetes. The data indicate that environmental contamination has not resulted in a highly polluted environment with a significant reduction in fauna. It would seem that the river flow and intense hydrodynamics dilute and minimize the effects of contaminants in the estuary. The main effect of the discharge effluents was a favorable organic enrichment. The fauna at the impacted sites was generally more diverse than at the non-impacted sites, dominated by Oligochaeta Tubificinae, and showed greater spatial heterogeneity.
\end{abstract}

Keywords: benthos, pollution effects, effluents, organic enrichment, spatial and temporal variation, Amazon estuary.

RESUMEN: CAMBios eSPACIALES Y TEMPORALES EN LAS COMUNIDADES DE MACROINVERTEBRAdOS BENTÓNICOS EN LA zona costera del Amazonas (Estuario del Guajará, Brasil), CaUSADa POR los Vertidos de efluentes uRbanos. - Se estudiaron los cambios espacio-temporales en la estructura de las comunidades de macroinvertebrados bentónicos causados por los vertidos de agua residuales urbanas en la Estuario del Guajará, zona costera del Amazonas, Brasil. Se recolectaron las muestras durante la estación seca y lluviosa, en cinco sitios próximos a las fuentes de los vertidos (impactados) y en dos sitios más lejanos de las aguas residuales (no impactados). Las muestras de sedimento se recolectaron con una draga Petersen $(20 \times 20 \times 20 \mathrm{~cm})$ y se pasaron a través de una malla de $0.3 \mathrm{~mm}$. En cada sitio se determinaron varios parámetros para caracterizar el agua y el sedimento. La fauna bentónica estuvo compuesta por 22 taxones, con predominio de los anélidos poliquetos y oligoquetos. Los datos indican que la contaminación ambiental no se ha traducido en un ambiente altamente contaminado con una reducción significativa de la fauna. Se cree que el caudal del río y la hidrodinámica intensa diluye y minimiza los efectos de los contaminantes en el estuario. El principal efecto de los efluentes de descarga fue el enriquecimiento orgánico favorable. La fauna en los sitios afectados fue en general: más diversa que en los sitios no afectados, dominado por Oligochaeta Tubificinae y mostró una mayor heterogeneidad espacial.

Palabras clave: bentos, efectos de la contaminación, aguas residuales urbanas, enriquecimiento orgánico, variación espacial y temporal, estuario del Amazonas.

\section{INTRODUCTION}

Benthic organisms are among the first components of aquatic communities to respond to the effects of environmental disturbance due to their relatively sedentary nature and intimate contact with sediment and pollutants, and display varying degrees of tolerance to human disturbance (Rosenberg and Resh 1993).

Spatial and temporal changes in the structure of benthic communities, such as the loss of species or changes 
in the distribution and abundance of species, in coastal regions have often been identified as responses to environmental disturbances caused by the degradation of waterbodies (Kennish 1997). Among the wide range of anthropogenic activities that affect the environmental quality of aquatic systems and their communities, the discharge of urban effluents is certainly one of the most frequent and harmful, given the multiplicity of the pollutants that they contain (Clark 2002).

Although studies addressing the effects of pollution on benthic communities have been carried out for more than a century, especially in fresh water (Rosenberg and Resh 1993), and have intensified in recent decades in marine and estuarine environments (Kennish 1997), there are still few studies in Brazil and the rest of Latin America that analyze the environmental pressure in coastal zones (e.g. Elias et al. 2003, Elias et al. 2005, Pagliosa and Barbosa 2006). Historical information and continuous monitoring are rare. Cause-and-effect relationships have only been recorded when the impact caused by pollution is obvious (Bemvenuti et al. 2003, Venturini et al. 2008) or in experimental studies (Mayer-Pinto and Junqueira 2003).

Amazonian estuaries, formed by the interaction of waters from the Amazon River and its tributaries with waters of the Atlantic Ocean, are ecosystems in which enormous discharges of fresh water dictate unusual hydrodynamic patterns (Nittrouer and DeMaster 1996), resulting in one of the greatest biological diversities on the planet. Although the region is relatively underpopulated, uncontrolled human occupation along some parts of the northern coast of Brazil has been gradually compromising the quality of estuarine environments in the region.

The city of Belém, with approximately 1.4 million inhabitants and a demographic density of 1315 inhabitants $\mathrm{km}^{-2}$, is the largest urban center in the Amazon region (IBGE 2010). The city produces about 274.5 million liters of sewage per day, of which only $8 \%$ passes through a collection system and no more than $3 \%$ of that is treated before being released directly into streams and soil (IBGE 2008).

A number of studies have demonstrated that urban effluents in the Guajará Estuary are causing the loss of water quality as well as sediment quality. At points near effluent sources, total fecal coliform concentrations as much as 1000 times the amount recommended by the World Health Organization have been recorded (Ramos 2004), along with low values of dissolved oxygen (mean $0.7 \mathrm{mg} \mathrm{L}^{-1}$ ), high oil and grease content (maximum values above $2000 \mathrm{ppm}$ ), and an increase in nitrogenated compounds (Lima and Santos 2001). High concentrations of metallic pollutants have been detected in the sediment, with mean levels of nickel above those permitted by Brazilian legislation (Corrêa and Pereira 2002).

Despite the existing indications regarding contamination of the Guajará Estuary, no studies have assessed the effects of pollutant discharge on the resident biota.

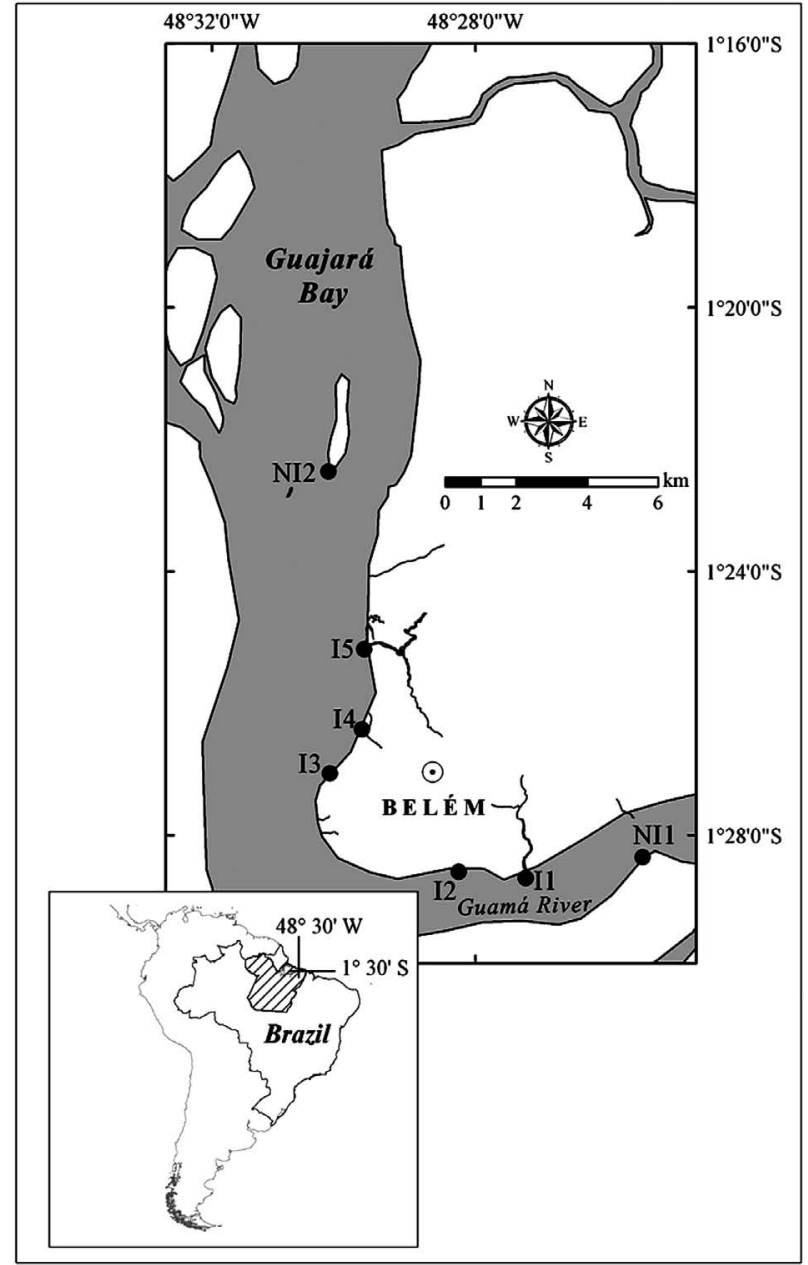

FIG. 1. - Study area in the Guajará Estuary showing the sampling sites.

There are few studies on the biological diversity of the area, and the benthic community is unknown. The purpose of the present study was to investigate the hypothesis that urban waste water is causing spatio-temporal changes in the structure of macrobenthic communities in the Guajará Estuary by comparing sites near urban effluent sources with sites further away from these sources.

\section{MATERIALS AND METHODS}

\section{Study area}

The city of Belém in the state of Pará (Brazil) is located $173 \mathrm{~km}$ from the Atlantic Ocean on the right shore of the Guajará Estuary (Fig. 1). Approximately $30 \%$ of the population lives in peripheral areas of the city, which are subject to periodic tidal flooding and a general lack of basic sanitation services.

The Guajará Estuary $\left(01^{\circ} 27^{\prime} \mathrm{S} 48^{\circ} 30^{\prime} \mathrm{W}\right)$ is formed by the confluence of the Guamá and Acará Rivers. On the Belém waterfront, this confluence is called locally Guajará Bay (Fig. 1). The system makes up a small portion of the estuary of the Amazon River, in a region 
under strong riverine influence, especially from the Amazon and Pará Rivers (Pinheiro 1987). The large fluvial discharge nearly completely prevents brackish waters from the Atlantic penetrating the estuary, so that the entire estuary is oligohaline (salinity between 0 and 10 ) in character all year round. The region is directly influenced by semi-diurnal tides, with a mean amplitude of $3.35 \mathrm{~m}$ during spring tides and $3.17 \mathrm{~m}$ during neap tides (Pinheiro 1987). During the ebb spring tide, surface currents in the estuary can reach 1.9 to $2.2 \mathrm{~m} \mathrm{~s}^{-1}$.

There are two types of bottom sediments: i) muddy (silts, clays and mixtures thereof), found in marginal regions of the estuary; and ii) sandy (sands and silty sands), found on different banks, partially filling the channels and around the central channel of the Guamá River (Pinheiro 1987).

Secondary forest and floodplain vegetation border the estuary. The floodplain vegetation is typical of areas that undergo inundation, and predominates in approximately $60 \%$ of the area. In a large portion of the southern margin, along the Belém waterfront, the vegetation has either been replaced with pioneering vegetation or completely removed (Pinheiro 1987).

The region has a humid tropical climate, with air temperatures ranging from 24 to $32^{\circ} \mathrm{C}$ (always above $18^{\circ} \mathrm{C}$ ) with a yearly oscillation of less than $5^{\circ} \mathrm{C}$. Rainfall patterns define two seasons: a rainy season (January to June), with mean monthly precipitation of 1657 $\mathrm{mm}$; and a dry season (July to December), with mean monthly precipitation of $487 \mathrm{~mm}$ (Moraes et al. 2005).

\section{Sampling}

Sampling was carried out on four occasions, two in the dry season (December 2004 and September 2005) and two in the rainy season (March and June 2005). Seven sampling sites were established: five located on the margin near sources of urban effluents and considered impacted (I1 to I5); and two on river islands on the northern margin, located far from the influence of effluents and considered non-impacted reference sites (NI1 and NI2) (Fig. 1). The northern shore of the estuary is very sparsely populated, and previous studies have shown that the influence of contaminants from urban effluents is hardly noticeable in this area (Ramos 2004).

On each occasion, four biological samples and one sample for analyzing sediment characteristics were collected from each site with a Petersen grab $(0.039$ $\mathrm{m}^{2}$ ). The depth of the collection sites ranged from 1.0 to $2.0 \mathrm{~m}$. The biological samples were passed through a $0.3-\mathrm{mm}$ mesh and the material retained was fixed in $5 \%$ saline formalin. Sediment samples were chilled and later frozen.

In parallel to the sediment sampling, a surface-water sample was collected at each site with a van Dorn bottle (2.5 1). In situ measurements were taken of $\mathrm{pH}$, electrical conductivity, and temperature. The samples were later filtered, fixed, or chilled.
Sediment parameters determined were: texture (\% sand, silt, and clay) (Suguio 1973), organic matter content (Walkley and Black 1934), phosphorus concentration, total nitrogen concentration (Riley 1958), and the concentration of heavy metals (chrome, copper, nickel, zinc and ferrous oxide) (APHA 1992). The following characteristics were determined in the water samples: chemical oxygen demand (COD), oxygen consumption (CO) (CETESB 1977), and the concentrations of total inorganic phosphorus, nitrate and ammonium (APHA 1992).

\section{Statistical analysis}

For each biological sample, density (ind. $\mathrm{m}^{-2}$ ), richness (total number of taxa), diversity (Shannon-Wiener $\mathrm{H}^{\prime}$ ) and evenness (Pielou J') were calculated. Two-way analysis of variance (ANOVA) was used to compare the mean values of these descriptors between sites (impacted and non-impacted) and the climate periods (rainy or dry season) of the sampling. Prior to ANOVA, the normality of the data distribution (KolmogorovSmirnov test) and homoscedasticity of the variances (Shapiro-Wilk test) were tested. When necessary, the raw data were log-transformed $(x+1)$.

$\mathrm{K}$-dominance curves were plotted for the sites in each season. Caswell's V-Statistic Index (Clarke and Warwick 1994) was used to detect changes in biological diversity stemming from environmental contamination. The Multivariate Dispersion Index (MDI) (Clarke and Warwick 1994) was used to identify increases in variability between the biological replicates.

To represent and compare the structure of the benthic communities between collection sites and seasons, ordination (MDS) and similarity (ANOSIM) analyses were performed based on similarity matrices calculated from mean density values per taxon and square-root transformed using the Bray-Curtis index.

Environmental data, $\log (x+1)$ transformed and normalized, were analyzed using principal components analysis (PCA; Euclidian distance). The most important environmental variables related to faunal patterns were identified using canonical correspondence analysis (CCA). Biological data were fourth-root transformed, and environmental data were standardized and log-transformed $(\mathrm{x}+1)$. Prior to the PCA and CCA, the Draftsman plot routine was used to identify potential collinearity among environmental variables, excluding those that were strongly correlated $(\mathrm{r} \geq 0.8)$. The statistical analyses were performed using the computer programs PRIMER ${ }^{\circledR} 6.0$ and STATISTICA $® 8.0$.

\section{RESULTS}

\section{Physical and chemical parameters}

The estuary water was warm (above $30^{\circ} \mathrm{C}$ ), with a narrow temperature range $\left(1\right.$ to $\left.3^{\circ} \mathrm{C}\right)$, and acidic ( $\mathrm{pH}$ between 5.2 and 6.1), and had a wide range of different concentra- 
TABLE 1. - Water physical and chemical characteristics. Values (mean \pm SE) are shown for each sampling season. I, impacted sites; NI, nonimpacted sites; T, temperature; $\mathrm{CO}$, consumed oxygen; $\mathrm{COD}$, chemical oxygen demand.

\begin{tabular}{|c|c|c|c|c|c|c|c|c|}
\hline Sites & $\mathrm{T}\left({ }^{\circ} \mathrm{C}\right)$ & $\mathrm{pH}$ & $\begin{array}{l}\text { Conductivity } \\
\left(\mu \mathrm{S} \mathrm{cm}^{-1}\right)\end{array}$ & $\begin{array}{l}\text { Phosphorus } \\
\left(\mathrm{mg} \mathrm{L}^{-1}\right)\end{array}$ & $\begin{array}{l}\text { Nitrate } \\
\left(\mathrm{mg} \mathrm{L}^{-1}\right)\end{array}$ & $\underset{\left(\mathrm{mg} \mathrm{L}^{-1}\right)}{\text { Ammonium }}$ & $\underset{\left(\mathrm{mg} \mathrm{L}^{-1}\right)}{\mathrm{CO}}$ & $\underset{\left(\mathrm{mg} \mathrm{L}^{-1}\right)}{\mathrm{COD}}$ \\
\hline NI1 & $31.5 \pm 0.5$ & $5.7 \pm 0.0$ & $171.0 \pm 115.1$ & $0.03 \pm 0.02$ & $0.7 \pm 0.6$ & $0.2 \pm 0.2$ & $1.9 \pm 0.7$ & $17.7 \pm 0.7$ \\
\hline I1 & $31.5 \pm 0.5$ & $5.9 \pm 0.1$ & $231.7 \pm 179.4$ & $0.02 \pm 0.01$ & $0.8 \pm 0.0$ & $0.2 \pm 0.1$ & $1.8 \pm 0.5$ & $26.5 \pm 1.1$ \\
\hline $\mathrm{I} 2$ & $30.8 \pm 0.3$ & $6.2 \pm 0.3$ & $227.3 \pm 214.8$ & $0.01 \pm 0.00$ & $1.1 \pm 0.2$ & $0.4 \pm 0.2$ & $2.8 \pm 1.3$ & $30.8 \pm 3.2$ \\
\hline $\mathrm{I} 3$ & $31.5 \pm 0.5$ & $6.1 \pm 0.2$ & $323.8 \pm 204.2$ & $0.02 \pm 0.02$ & $1.2 \pm 0.1$ & $0.5 \pm 0.2$ & $2.6 \pm 1.0$ & $13.1 \pm 3.9$ \\
\hline I4 & $30.8 \pm 0.3$ & $6.2 \pm 0.2$ & $323.8 \pm 191.3$ & $0.02 \pm 0.01$ & $1.3 \pm 0.3$ & $0.4 \pm 0.2$ & $1.9 \pm 0.7$ & $17.7 \pm 0.7$ \\
\hline I5 & $31.0 \pm 0.0$ & $6.2 \pm 0.2$ & $338.0 \pm 206.1$ & $0.02 \pm 0.02$ & $0.9 \pm 0.1$ & $0.5 \pm 0.2$ & $2.2 \pm 0.6$ & $13.2 \pm 3.9$ \\
\hline NI2 & $31.0 \pm 0.0$ & $6.0 \pm 0.1$ & $319.0 \pm 76.0$ & $0.01 \pm 0.01$ & $0.3 \pm 0.3$ & $0.1 \pm 0.0$ & $2.0 \pm 1.1$ & $13.1 \pm 3.9$ \\
\hline \multicolumn{9}{|l|}{ Rainy season } \\
\hline NI1 & $31.0 \pm 0.0$ & $5.3 \pm 0.1$ & $25.7 \pm 7.2$ & $0.02 \pm 0.02$ & $1.3 \pm 1.1$ & $0.2 \pm 0.0$ & $5.9 \pm 1.2$ & $17.2 \pm 4.7$ \\
\hline I1 & $32.0 \pm 0.0$ & $5.3 \pm 0.1$ & $30.9 \pm 4.4$ & $0.03 \pm 0.03$ & $1.4 \pm 0.3$ & $0.2 \pm 0.0$ & $6.4 \pm 0.6$ & $30.3 \pm 4.9$ \\
\hline $\mathrm{I} 2$ & $32.0 \pm 0.0$ & $5.5 \pm 0.1$ & $34.6 \pm 6.8$ & $0.03 \pm 0.00$ & $3.1 \pm 1.4$ & $0.7 \pm 0.3$ & $6.3 \pm 1.1$ & $21.8 \pm 3.4$ \\
\hline I3 & $32.5 \pm 0.5$ & $5.5 \pm 0.1$ & $31.9 \pm 8.1$ & $0.03 \pm 0.02$ & $2.1 \pm 1.4$ & $0.5 \pm 0.3$ & $6.3 \pm 0.5$ & $13.0 \pm 4.6$ \\
\hline I4 & $32.5 \pm 0.5$ & $5.4 \pm 0.1$ & $25.4 \pm 3.8$ & $0.03 \pm 0.00$ & $1.0 \pm 0.1$ & $0.3 \pm 0.1$ & $5.6 \pm 0.8$ & $13.2 \pm 13.2$ \\
\hline I5 & $32.0 \pm 0.0$ & $5.6 \pm 0.2$ & $40.6 \pm 11.8$ & $0.01 \pm 0.01$ & $1.1 \pm 0.2$ & $0.4 \pm 0.1$ & $6.0 \pm 1.3$ & $8.8 \pm 8.8$ \\
\hline NI2 & $32.5 \pm 0.5$ & $5.7 \pm 0.3$ & $35.6 \pm 0.1$ & $0.02 \pm 0.00$ & $0.8 \pm 0.1$ & $0.2 \pm 0.1$ & $5.7 \pm 0.9$ & $13.0 \pm 4.6$ \\
\hline
\end{tabular}

TABLE 2. - Sediment chemical characteristics. Values (mean \pm SE) are shown for each sampling season. I, impacted sites; NI, non-impacted sites. OM, organic matter.

\begin{tabular}{|c|c|c|c|c|c|c|c|c|c|c|c|}
\hline Sites & Sandy (\%) & Silt (\%) & Clay (\%) & $\mathrm{OM}(\%)$ & $\mathrm{P}\left(\mathrm{mg} \mathrm{dm}^{-3}\right)$ & $\mathrm{N}(\%)$ & $\mathrm{Cr}(\mathrm{ppm})$ & $\mathrm{Cu}(\mathrm{ppm})$ & $\mathrm{Ni}(\mathrm{ppm})$ & $\mathrm{Zn}(\mathrm{ppm})$ & $\mathrm{Fe}_{2} \mathrm{O}_{3}(\%)$ \\
\hline \multicolumn{12}{|c|}{ Dry season } \\
\hline NI1 & $10.5 \pm 3.6$ & $81.4 \pm 1.6$ & $8.1 \pm 2.1$ & $0.5 \pm 0.4$ & $19.5 \pm 0.0$ & $0.1 \pm 0.0$ & $74.5 \pm 17.5$ & $17.5 \pm 0.5$ & $38.5 \pm 0.5$ & $83.0 \pm 15.0$ & $4.2 \pm 0.4$ \\
\hline I1 & $46.9 \pm 13.3$ & $49.0 \pm 12.2$ & $4.2 \pm 1.1$ & $0.5 \pm 0.2$ & $21.5 \pm 0.1$ & $0.1 \pm 0.1$ & $57.5 \pm 13.5$ & $12.5 \pm 1.5$ & $31.5 \pm 0.5$ & $75.5 \pm 24.5$ & $4.2 \pm 0.2$ \\
\hline $\mathrm{I} 2$ & $37.1 \pm 27.9$ & $57.9 \pm 26.4$ & $5.1 \pm 1.5$ & $0.4 \pm 0.1$ & $66.0 \pm 0.0$ & $0.2 \pm 0.1$ & $87.0 \pm 17.0$ & $33.0 \pm 2.0$ & $47.0 \pm 1.0$ & $134.0 \pm 32.0$ & $5.0 \pm 0.2$ \\
\hline I3 & $46.6 \pm 38.1$ & $45.6 \pm 33.7$ & $7.9 \pm 4.4$ & $0.4 \pm 0.2$ & $160.0 \pm 0.1$ & $0.1 \pm 0.0$ & $76.0 \pm 15.0$ & $18.5 \pm 1.5$ & $40.0 \pm 1.0$ & $81.0 \pm 8.0$ & $4.2 \pm 0.1$ \\
\hline I4 & $33.3 \pm 19.3$ & $62.3 \pm 17.0$ & $4.4 \pm 2.3$ & $0.5 \pm 0.2$ & $49.0 \pm 0.0$ & $0.1 \pm 0.1$ & $73.5 \pm 8.5$ & $23.0 \pm 0.0$ & $40.0 \pm 3.0$ & $104.5 \pm 9.5$ & $4.1 \pm 0.2$ \\
\hline I5 & $12.8 \pm 0.4$ & $75.1 \pm 9.0$ & $12.2 \pm 8.6$ & $1.2 \pm 0.2$ & $40.5 \pm 0.2$ & $0.1 \pm 0.1$ & $64.5 \pm 8.5$ & $14.5 \pm 0.5$ & $33.0 \pm 2.0$ & $86.5 \pm 22.5$ & $3.5 \pm 0.1$ \\
\hline NI2 & $5.4 \pm 2.5$ & $81.0 \pm 3.6$ & $13.6 \pm 1.1$ & $0.8 \pm 0.2$ & $20.5 \pm 0.0$ & $0.2 \pm 0.1$ & $85.0 \pm 15.0$ & $20.0 \pm 1.0$ & $47.0 \pm 5.0$ & $131.5 \pm 61.5$ & $4.1 \pm 0.9$ \\
\hline \multicolumn{12}{|c|}{ Rainy season } \\
\hline NI1 & $22.2 \pm 1.0$ & $71.0 \pm 0.0$ & $6.9 \pm 0.9$ & $0.2 \pm 0.0$ & $7.5 \pm 0.0$ & $0.1 \pm 0.0$ & $28.0 \pm 17.5$ & $8.0 \pm 0.5$ & $24.5 \pm 4.0$ & $28.0 \pm 86.5$ & $1.8 \pm 0.6$ \\
\hline I1 & $21.6 \pm 7.8$ & $71.8 \pm 9.5$ & $6.6 \pm 1.8$ & $0.3 \pm 0.3$ & $22.8 \pm 0.0$ & $0.1 \pm 0.0$ & $59.8 \pm 13.5$ & $15.8 \pm 1.5$ & $39.8 \pm 6.5$ & $66.5 \pm 71.0$ & $3.7 \pm 0.3$ \\
\hline I2 & $22.8 \pm 13.9$ & $72.0 \pm 13.6$ & $5.2 \pm 0.3$ & $0.4 \pm 0.0$ & $27.8 \pm 0.0$ & $0.1 \pm 0.0$ & $57.3 \pm 15.0$ & $16.3 \pm 1.5$ & $41.8 \pm 7.5$ & $75.3 \pm 158.0$ & $.0 \quad 4.0 \pm 0.1$ \\
\hline I3 & $29.1 \pm 11.9$ & $66.0 \pm 11.5$ & $4.9 \pm 0.3$ & $0.4 \pm 0.0$ & $50.5 \pm 0.0$ & $0.3 \pm 0.0$ & $76.0 \pm 5.0$ & $33.5 \pm 6.5$ & $50.0 \pm 9.0$ & $107.0 \pm 26.0$ & $4.5 \pm 0.1$ \\
\hline I4 & $20.8 \pm 7.4$ & $72.6 \pm 6.5$ & $6.6 \pm 0.9$ & $0.4 \pm 0.1$ & $117.0 \pm 0.0$ & $0.1 \pm 0.0$ & $67.0 \pm 19.0$ & $21.8 \pm 0.5$ & $45.0 \pm 4.0$ & $85.0 \pm 47.5$ & $4.0 \pm 0.6$ \\
\hline I5 & $24.1 \pm 9.9$ & $70.5 \pm 11.4$ & $5.4 \pm 1.5$ & $0.5 \pm 0.0$ & $42.0 \pm 0.0$ & $0.1 \pm 0.0$ & $61.8 \pm 29.0$ & $21.0 \pm 0.5$ & $41.5 \pm 3.5$ & $84.3 \pm 39.0$ & $3.7 \pm 1.0$ \\
\hline NI2 & $5.4 \pm 1.3$ & $90.1 \pm 1.7$ & $4.5 \pm 0.4$ & $0.7 \pm 0.1$ & $35.3 \pm 0.0$ & $0.1 \pm 0.0$ & $58.3 \pm 23.5$ & $16.3 \pm 0.5$ & $39.5 \pm 1.0$ & $71.8 \pm 89.0$ & $3.4 \pm 1.0$ \\
\hline
\end{tabular}

tions of dissolved salts (conductivity from 12.5 to $544 \mu \mathrm{S}$ $\mathrm{cm}^{-1}$ ) (Table 1). The sediment was mainly fine-grained, with a predominance of silt in most places, and low concentrations of organic matter (Table 2).

Except for temperature, the physical and chemical characteristics of the water exhibited a strong seasonal pattern, with spatial differences associated with the entrance of fresh water and/or proximity to effluent sources. Thus, the $\mathrm{pH}$ and conductivity of the water were higher in the dry season and at sites near the mouth of the estuary. Higher values of the environmental parameters most directly associated with contamination (phosphorus, nitrogen compounds, heavy metals and oxygen demand rates) were recorded in the rainy season and at impacted sites (Tables 1 and 2).

The principal components analysis (PCA) produced two principal vectors that collectively explained $68 \%$ of the variance of the environmental data (Fig. 2). The analysis revealed a natural pattern of variation, as well as the effects of the presence of urban wastewater discharges in the estuary. Samples from the two seasons are separated on the first axis (eigenvalue $=7.12$ ), which explained $51 \%$ of the data variation, mainly due to the lower

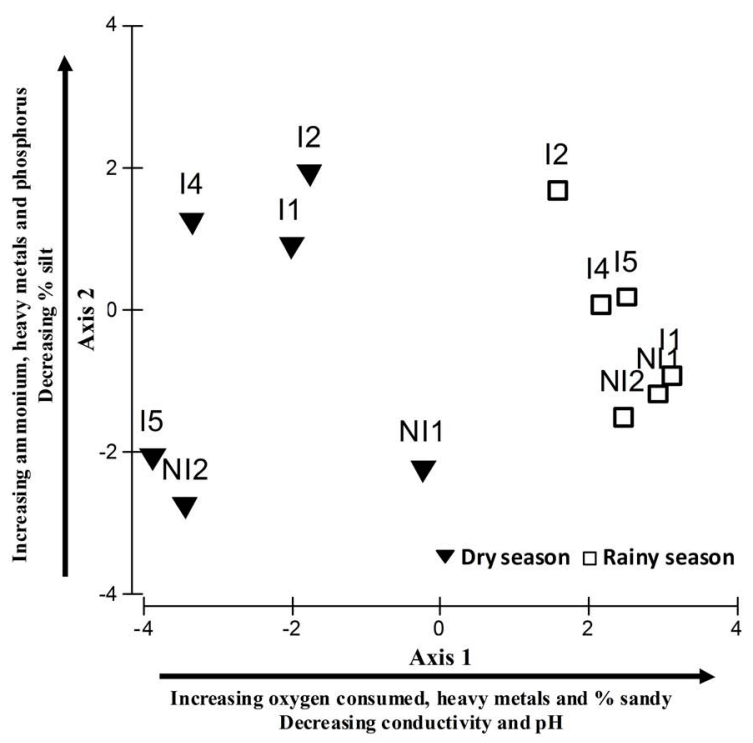

FIG. 2. - Principal components analysis (PCA) biplot for the water and sediment variables, the sites and seasons sampled are indicated. The first and second axes explained $51 \%$ and $17 \%$ of the variation, respectively. NI, non-impacted sites; I, impacted sites. 
TABLE 3. - List of taxa (mean density \pm SE) for the benthic macrofauna in the Guajará Estuary.

\begin{tabular}{|c|c|c|c|c|}
\hline \multirow[t]{2}{*}{ Taxon } & \multicolumn{2}{|c|}{ Dry season } & \multicolumn{2}{|c|}{ Rainy season } \\
\hline & Impacted site & Non-impacted site & Impacted site & Non-impacted site \\
\hline Nemertea & $2.6 \pm 1.4$ & - & $1.3 \pm 0.9$ & $6.4 \pm 3.9$ \\
\hline Cyanocyclas sp. (Bivalvia, Mollusca) & $2.6 \pm 2.0$ & $6.4 \pm 2.8$ & - & - \\
\hline Bivalvia unidentified juvenile (Mollusca) & $1.3 \pm 0.9$ & - & $0.6 \pm 0.6$ & - \\
\hline Namalycastis abiuma (Grube, 1872) (Polychaeta, Annelida) & $501.9 \pm 74.6$ & $254.8 \pm 48.8$ & $1148.7 \pm 120.4$ & $873.4 \pm 411.3$ \\
\hline Nephtys fluviatilis Monro, 1937 (Polychaeta, Annelida) & $869.9 \pm 452.1$ & $168.3 \pm 37.5$ & $578.2 \pm 127.6$ & $668.3 \pm 242.2$ \\
\hline Mediomastus sp. (Polychaeta, Annelida) & $13.5 \pm 5.1$ & $9.6 \pm 5.3$ & $17.9 \pm 5.1$ & $439.1 \pm 148.3$ \\
\hline Eteone heteropoda Hartman, 1951 (Polychaeta, Annelida) & $11.5 \pm 7.9$ & - & $65.4 \pm 19.6$ & $3.2 \pm 1.4$ \\
\hline Tubificinae (Oligochaeta, Annelida) & $10489.1 \pm 9356.6$ & $25.6 \pm 6.9$ & $3976.9 \pm 832.7$ & $48.1 \pm 15.1$ \\
\hline Naidinae (Oligochaeta, Annelida) & $2000.6 \pm 1908.7$ & $3.2 \pm 1.4$ & $1803.8 \pm 500.1$ & $6.4 \pm 5.6$ \\
\hline Enchytraeidae (Oligochaeta, Annelida) & - & $6.4 \pm 2.8$ & - & - \\
\hline Opistocysta funiculus Cordero, 1948 (Oligochaeta, Annelida) & - & - & $6.4 \pm 2.2$ & - \\
\hline Euhirudinea (Hirudinea, Annelida) & $7.7 \pm 7.7$ & - & $2.6 \pm 2.0$ & - \\
\hline Dexaminidae (Amphipoda, Crustacea) & $1.3 \pm 0.6$ & - & - & - \\
\hline Cumacea (Cumacea, Crustacea) & $39.1 \pm 11.6$ & - & $3.8 \pm 1.9$ & - \\
\hline Zeuxo coralensis Sieg, 1980 (Tanaidacea, Crustacea) & - & $1.3 \pm 0.6$ & - & - \\
\hline Ostracoda (Crustacea) & - & $144.2 \pm 71.6$ & - & - \\
\hline Decapoda (megalopa) (Crustacea) & $0.6 \pm 0.6$ & - & - & - \\
\hline Chironominae (larvae) (Arthropoda) & $4.5 \pm 3.2$ & $136.2 \pm 53.6$ & $4.5 \pm 2.2$ & $1.6 \pm 1.4$ \\
\hline Sphaeroceridae (larvae) (Arthropoda) & $0.6 \pm 0.6$ & - & - & - \\
\hline Diptera sp.1 (larvae) (Arthropoda) & $0.6 \pm 0.6$ & - & - & - \\
\hline Diptera sp. 2 (larvae) (Arthropoda) & $1.3 \pm 0.9$ & - & - & - \\
\hline Acarina (Arthropoda) & $1.3 \pm 0.9$ & - & $2.6 \pm 0.9$ & - \\
\hline Total abundance & $13950 \pm 11594$ & $756 \pm 65.0$ & $7612 \pm 2323$ & $2046 \pm 239$ \\
\hline Total number of taxa & 18 & 10 & 13 & 8 \\
\hline
\end{tabular}
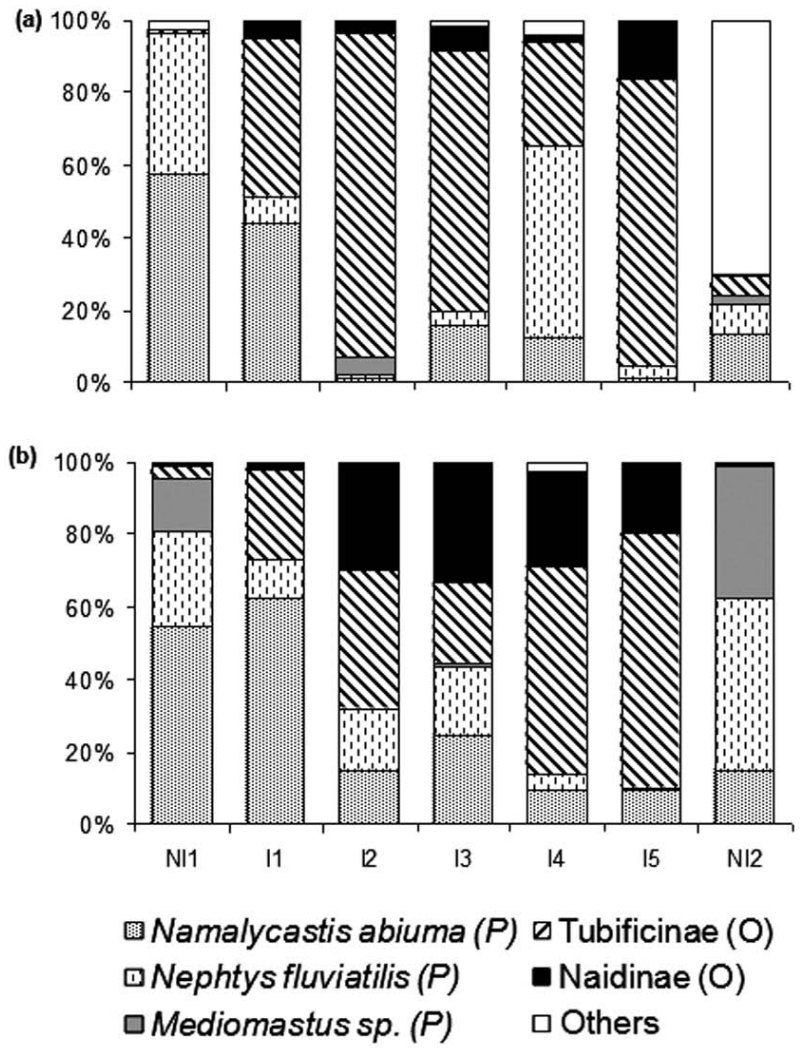

FIG. 3. - Percentage contribution of main taxa in the sites and seasons sampled. P, Polychaeta; O, Oligochaeta. Dry season (a) and

Rainy season (b). NI, non-impacted sites; I, impacted sites.

conductivity and $\mathrm{pH}$ in the rainy season as well as the increase in oxygen consumption in the water and heavy metals in the sediment and sand (Tables 1 and 2). The second axis (eigenvalue $=2.35$ ), explaining $17 \%$ of the variance, was particularly influenced by the concentrations of ammonium in the water and phosphorus and sand in the sediment, which were higher at the sites close to urban effluents (Tables 1 and 2).

\section{Macrobenthic communities}

A total of 22 taxa, ten of which were Annelida, were recorded (Table 3 ). The impacted sites had a higher abundance of nearly all taxa, as well as greater richness in both seasons. Annelida was both the most diverse group and the most abundant, comprising over $99 \%$ of the total number of individuals. The main taxa responsible for the dominance of the group were the polychaetes Namalycastis abiuma (Grube, 1872), Nephtys fluviatilis Monro, 1937 and Mediomastus sp., and the Naididae oligochaetes (Tubificinae and Naidinae).

Although the polychaetes and oligochaetes occurred in both seasons and at all sites in the estuary, their distribution was not homogeneous, especially in relation to areas of human impact (Fig. 3). In both seasons, the impacted sites had higher densities of organisms (Table 3 ), as well as a high abundance of Oligochaeta, especially Tubificinae (Fig. 3). The opposite occurred at the non-impacted sites, where the polychaetes $N$. abiuma, $N$. fluviatilis and Mediomastus sp. were the dominant taxa (Fig. 3). The participation of Naidinae at the impacted sites increased in the rainy season, whereas the density of Mediomastus sp. increased at non-impacted sites (Fig. 3).

The spatio-temporal variation of the univariate descriptors is illustrated in Figure 4. Organism abundance and diversity were always higher in the rainy season and at the 

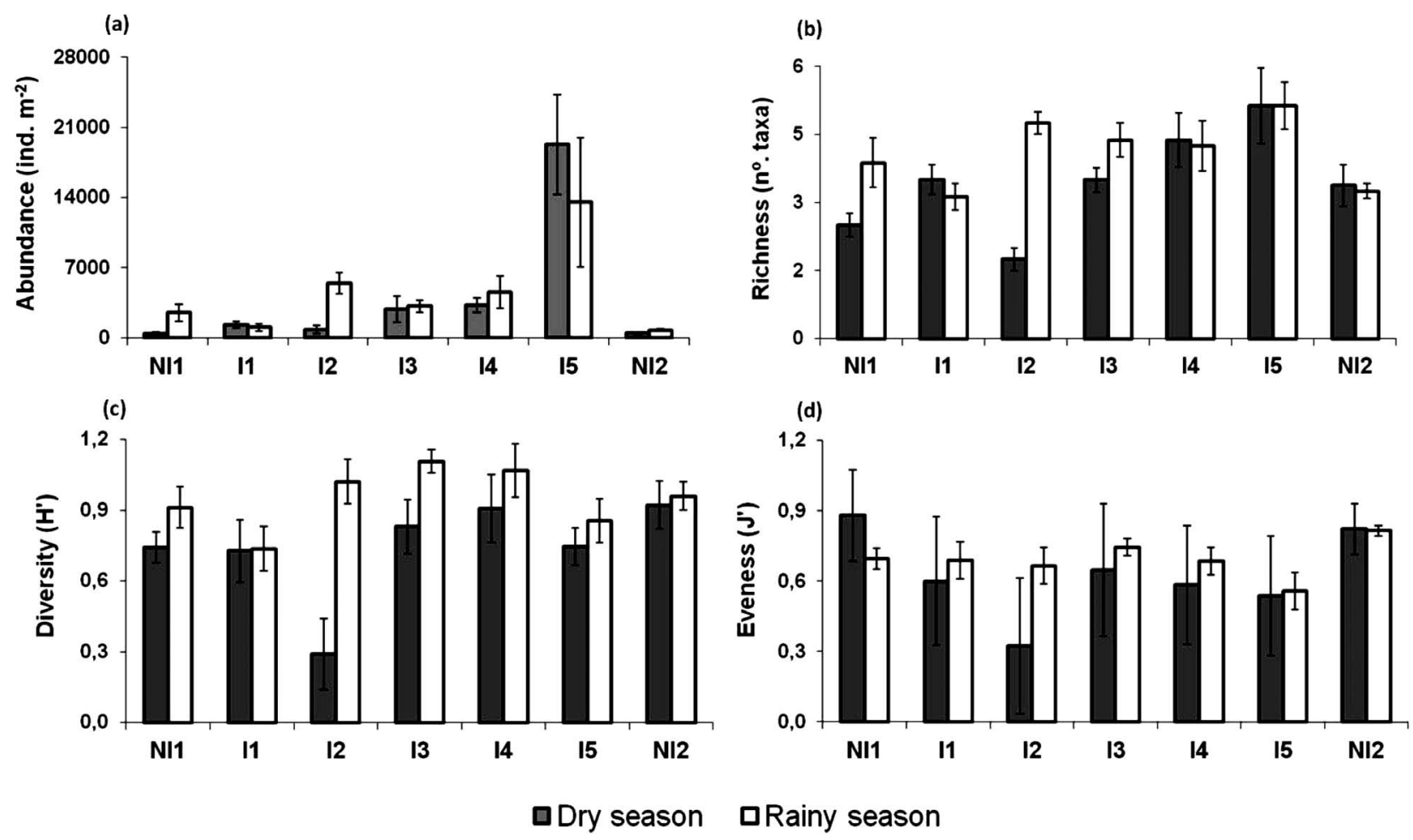

FIG. 4. - Biotic variables (mean \pm SE): abundance (a); richness (b); diversity (c) and evenness (d). I, impacted sites; NI, non-impacted sites.

TABLE 4. - Results of two-way (site and season) analysis of variance (ANOVA) for the biological variables; * Significant results.

\begin{tabular}{|c|c|c|c|c|c|c|c|c|}
\hline \multirow[t]{2}{*}{ Factor } & \multicolumn{2}{|c|}{ Abundance (ind. $\mathrm{m}^{-2}$ ) } & \multicolumn{2}{|c|}{ Richness (number of taxa) } & \multicolumn{2}{|c|}{ Diversity (H') } & \multicolumn{2}{|c|}{ Evenness (J') } \\
\hline & $\mathrm{F}$ & $\mathrm{P}$ & $\mathrm{F}$ & $\mathrm{P}$ & $\mathrm{F}$ & $\mathrm{P}$ & $\mathrm{F}$ & $\mathrm{P}$ \\
\hline Site & 17.72 & $0.00 .{ }^{*}$ & 4.75 & $0.037 *$ & 18.43 & $0.00 . . *$ & 0.45 & 0.504 \\
\hline Season & 3.18 & $0.00 . . *$ & 10.96 & $0.014 *$ & 0.04 & 0.843 & 6.81 & $0.010 *$ \\
\hline Site $\times$ Season & 3.62 & 0.297 & 4.75 & 0.902 & 5.12 & $0.022^{*}$ & 0.97 & 0.326 \\
\hline
\end{tabular}

impacted sites. The results of the analyses of variance often confirmed significant differences in the descriptors between sites (Table 4). The difference in density was one of the main aspects in the comparison between impacted and non-impacted sites. For example, in the dry season, site I5 had a mean density approximately 100 -fold higher than the reference sites (I5=59290 ind $\mathrm{m}^{-2} ; \mathrm{NI} 1=458$ ind $\mathrm{m}^{-2} ; \mathrm{NI} 2=490$ ind $\mathrm{m}^{-2}$ ).

The k-dominance curves were similar for the impacted and non-impacted sites, reinforcing the observation that in terms of abundance, the estuary is dominated by a small number of taxa. At the impacted sites, this tendency was somewhat more pronounced, with a single taxon (Tubificinae) representing more than $90 \%$ of the total number of organisms. At non-impacted sites, the dominance of the first-ranked taxon did not exceed $60 \%$ of the total abundance.

The Caswell analysis generated low V values, revealing conditions of low diversity throughout the entire estuary (Table 5). Similar patterns were obtained in both seasons, with minimum values recorded at impacted sites and maximum values at non-impacted sites. No significant deviation from the expected diversity $(\mathrm{V}> \pm$ 2.0) was detected at any site.
TABle 5. - Caswell V statistics for impacted sites (I) and nonimpacted sites (NI) in each sampling season.

\begin{tabular}{lcc}
\hline Site & Dry season & Rainy season \\
\hline NI1 & 1.0 & 0.5 \\
I1 & 1.0 & 1.1 \\
I2 & 0.1 & 0.2 \\
I3 & 1.0 & 1.3 \\
I4 & 0.3 & 1.8 \\
I5 & -0.7 & -0.8 \\
NI2 & 1.8 & 1.3 \\
\hline
\end{tabular}

The multivariate dispersion indices (MDI), shown in Table 6, demonstrated considerable spatial heterogeneity of the communities in the estuary. MDI values indicated that there were no significant differences between samples from impacted and non-impacted sites. Nonetheless, samples from the impacted sites were generally more dispersed.

The graph of the ordination analysis (MSD) only separated the samples from the impacted and nonimpacted sites in the rainy season (Fig. 5). The analysis of similarity (ANOSIM) confirmed the pattern obtained by the MDS, and only indicated a significant difference $(\mathrm{r}=0.651 ; \mathrm{p}=0.003)$ in the structure of the communities 
TABLE 6. - Index of Multivariate Dispersion (IMD) for impacted sites (I) and non-impacted sites (NI). Values of dispersion are shown for each sampling season.

\begin{tabular}{lcc}
\hline Site & Dry season & Rainy season \\
\hline NI1 & 0.634 & 0.861 \\
I1 & 0.818 & 0.530 \\
I2 & 0.390 & 1.043 \\
I3 & 1.437 & 0.994 \\
I4 & 1.413 & 1.314 \\
I5 & 1.054 & 0.928 \\
NI2 & 1.310 & 0.464 \\
NI $\times$ I & -0.156 & -0.447 \\
\hline
\end{tabular}

(a)

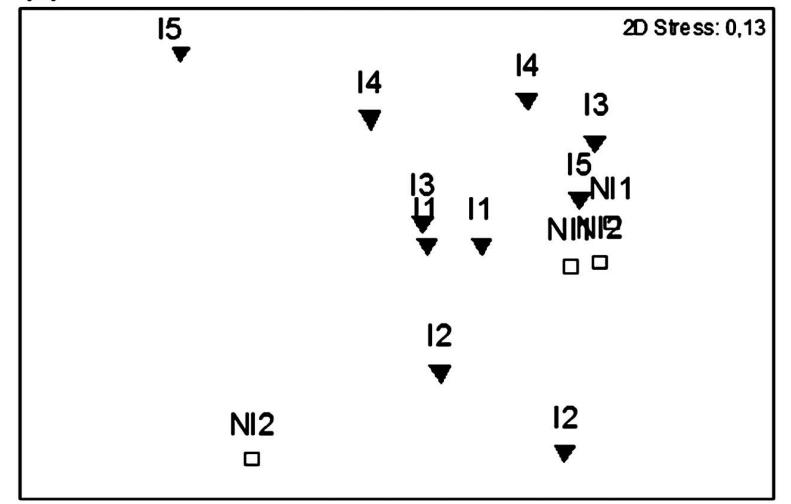

(b)

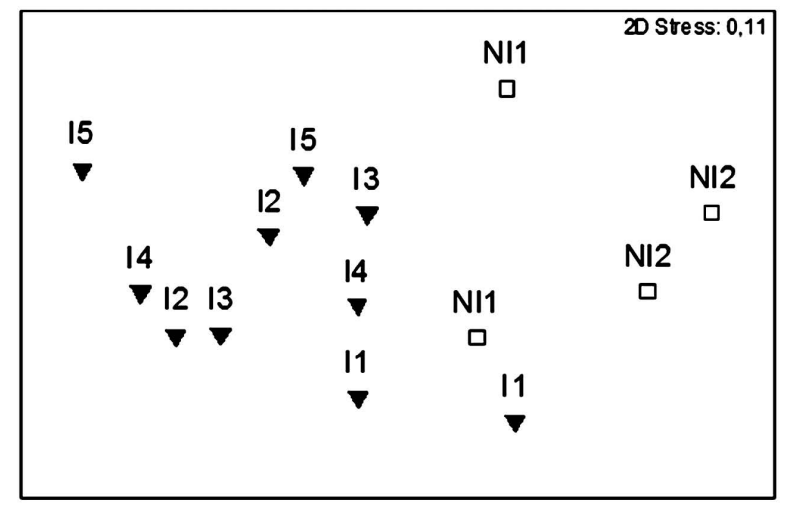

FIG. 5. - MDS plots of benthic community data performed with Bray-Curtis similarities. Abundance data were fourth-root transformed. (a) Dry season; (b) Rainy season. I, impacted sites; NI, non-impacted sites.

between sites during the rainy season. The structure of the communities also differed significantly $(\mathrm{r}=0.086$; $\mathrm{p}=0.03$ ) between climate periods, but still with high similarity, as indicated by the low r-value.

The results of the canonical correspondence analysis (CCA) explained $64.3 \%$ of the variation found, of which the first and second axes explained $47.1 \%$ and $17.2 \%$ of the variation, respectively. The CCA graph (Fig. 6) illustrates the separation between the samples from the impacted and non-impacted sites according to sediment and hydrological characteristics linked to human impact. The differences between sites occurred mainly because the impacted sites had sediment with lower proportions of silt (greater sand content) and higher

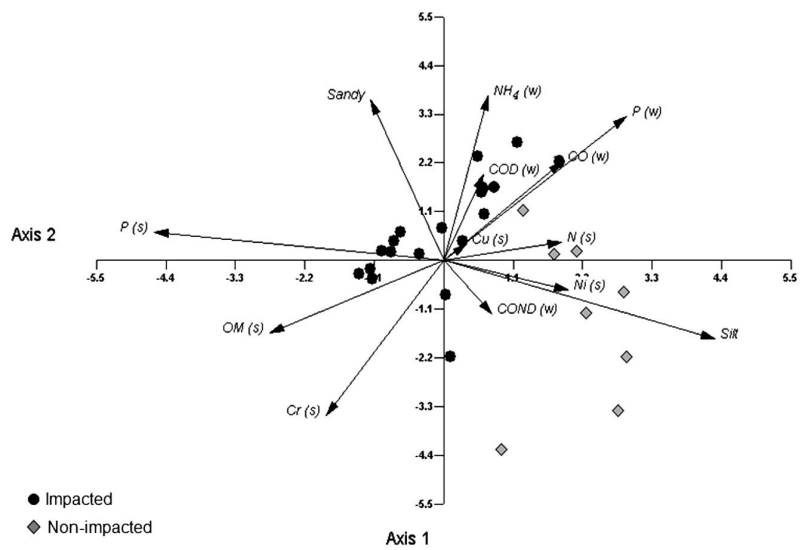

FIG. 6. - CCA ordination plot. In brackets are indications for water characteristics (w) and sediment characteristics (s). COND, electrical conductivity; $\mathrm{P}$, total phosphorus; COD, chemical oxygen demand; $\mathrm{CO}$, consumed oxygen; $\mathrm{NH}_{4}$, ammonium; OM, organic matter; $\mathrm{N}$, total nitrogen; $\mathrm{Cu}$, copper; $\mathrm{Cr}$, chromium; $\mathrm{Ni}$, nickel. The first and second axes explained $47.12 \%$ and $17.2 \%$ of the variation, respectively.

concentrations of ammonium, and the water had low oxygen levels (CO and COD). In contrast, non-impacted sites had sediment with higher silt content and water parameters that were less indicative of contamination.

\section{DISCUSSION}

The macrofauna in Guajará Bay is typically estuarine and composed predominantly of annelids, which is common for tropical estuaries (Flint and Younk 1983) with sediments rich in silt (Gray 1981). The macrofauna is naturally of low diversity and dominated by a small number of taxa. This is certainly a reflection of the low salinity (in the 0 to 5 range), in which the conditions for osmotic equilibrium are more complicated (Kinne 1971). Consequently, the fauna was dominated by species that commonly occur in oligohaline conditions, such as Namalycastis abiuma and Nephtys fluviatilis (Bemvenuti 1994, Santos and Lana 2001) and the tubificine oligochaetes (Caspers 1971).

The dumping of urban effluents into the estuary has not yet caused significant negative changes in the structure of the benthic communities. One of the most perceptible effects of the effluents was the increased density of organisms with no significant loss of diversity. This, together with the increase in organic compounds (principally in the water from contaminated sites), suggests that organic enrichment may be occurring at favorable levels for biostimulation.

Urban effluents rich in particulate organic matter but poor in toxic chemicals and heavy metals can favor benthic communities by increasing the food supply (Reish 1980, Holte and Oug 1996, De Paula et al. 2006). According to the conceptual model developed by Pearson and Rosenberg (1978), a positive stimulus for the biota occurs in the initial phases of organic enrichment, when the organic load does not compromise 
the availability of oxygen and is sufficient to attenuate competition between species.

Given that there is little industrial activity in the region, the urban effluents that enter the Guajará Estuary are mainly composed of urban sewage of household origin and are rich in particulate organic matter (Lima and Santos 2001, Corrêa and Pereira 2002). Although the estuary receives nearly all the household sewage produced by the city of Belém, the volume of contaminants appears to be as yet insufficient to actually pollute the environment and negatively impact the physical and chemical parameters and the benthic macrofauna of the estuary. These findings could be explained by the intensive hydrodynamics and enormous dilution of pollutants, as the estuary is a system with high hydraulic energy generated by the interaction of the tidal currents, fluvial discharge from rivers, and wind-generated waves. These agents lead to virtually constant mixing and resuspension of sediments along the banks and margins of the estuary (Pinheiro 1987).

The hydrodynamics of the estuary, for example, explains the low concentration of organic matter in the sediment compared with other estuarine areas under the influence of urban effluents (Grizzle and Penniman 1991, Holte and Oug 1996, Ferrando and Méndez 2011) or in conserved areas (Méndez 2002, Ysebaert et al. 2005). Due to this situation, severely polluted sites with marked changes in biological structure were only recorded on particular occasions and at particular sites, such as at I2, which is a port area heavily contaminated by solid and liquid wastes, and I5, which is near the main sewage effluent of the city of Belém.

Although discharges of urban wastewater have not caused a significant reduction in richness, diversity and abundance of macrofauna, such as occurs in severely impacted areas (Pearson and Rosenberg 1978), they influenced the distribution of Polychaeta and Oligochaeta in the estuary, and the latter group was dominant at impacted sites.

High densities of oligochaetes have also been reported in impacted areas with muddy and organically enriched sediment in estuaries and shallow-water marine habitats in temperate (Sardá et al. 1996, Warwick 2001) and tropical regions (Ferrando and Méndez 2011, Pagliosa and Barbosa 2006) of the world. The subfamily Tubificinae, the most abundant group in this study, is traditionally considered an opportunistic taxon associated with organic enrichment and which is tolerant of low oxygen levels (Caspers 1971, Pearson and Rosenberg 1978, McLusky et al. 1980).

According to Carpers (1971), in areas where pollution and physical factors result in an inhospitable environment or reduced habitat diversity, oligochaetes tend to increase in density due to a reduction in the polychaete fauna, which are intolerant of such conditions. This pattern occurred in the Guajará Estuary, where the oligochaetes, especially the Tubificinae, dominated at impacted sites, which had sediments con- taining a larger proportion of sand and/or the sites were organically enriched, they had higher concentrations of heavy metals, ammonium and phosphorus, as well as oxygen deficiency.

In marine environments, organic enrichment is often associated with peak densities of opportunistic polychaetes (Pearson and Rosenberg 1979, Sardá et al. 1992). But in the long term, enrichment is capable of causing a change in dominant species (Pearson and Rosenberg 1979, Sardá et al. 1996). Sardá et al. (1996), using an experimental approach in North American salt marshes, showed that after 15 years of enrichment the dominance of polychaetes and oligochaetes changed, and the latter dominated in the last years of the experiment.

The explanation of the dominance of oligochaetes lies in their ability to tolerate unfavorable environmental conditions for other organisms and to respond to organic enrichment with intense asexual reproduction, which leads to rapid increases in their populations over short periods of time (Giere and Pfannkuche 1982). Therefore, oligochaetes gradually replace the polychaete populations (Sardá et al. 1996).

Although the competition between polychaetes and oligochaetes needs to be researched further, a laboratory experiment carried out by McCann and Levin (1989) indicated that the presence of adults of the tubificine Monopylephorus evertus may be responsible for decreasing the growth of newly settled, older worms and the reproductive output in polychaete Streblospio benedicti.

In the Guajará Estuary, the dominance of oligochaetes was much more pronounced than in other organically enriched environments (Sardá et al. 1992, 1996, Pagliosa and Barbosa 2006, Ferrando and Méndez 2011), although the enrichment levels of the water and sediment and other environmental variables do not indicate that the environment is severely impacted. In this case, we should add to the enrichment, the strong influence of river discharges in determining the character of this oligohaline estuary, as they favor the persistence and proliferation of oligochaete populations throughout the year.

The relatively high organic matter content at the non-impacted site NI2 did not result in the dominance of Oligochaeta. At this site, the organic matter is basically composed of riparian vegetation litter. It is well known that not only the quantity, but also the quality of the organic matter are important for benthic organisms (Danovaro et al. 1999). The organic matter of plant origin is made up of complex substances - many are not labile (e.g. cellulose, resin, lignin) - which are degraded slowly, so that it takes more time for them to become available to deposit feeders (Henrichs 1992).

Important temporal changes were detected in the estuary. The rainy season was characterized by a drop in salinity and enrichment of the water, with an increase in macrofauna density and diversity. With the increase in rainfall, the greater flow of freshwater flushes more matter-including sediments, nutrients and pollutantsfrom the continent, as occurs in waterbodies all over the world (Kennish 1997, Kimmerer 2002). 
A number of studies have demonstrated that an increase in precipitation and a decrease in salinity in estuaries has a positive impact on the benthic macrofauna, resulting in an increase in the density, biomass and/or diversity of species that are capable of tolerating low salinity (Montagna and Yoon 1991, Montagna and Kalke 1992). It is also possible that the distribution and recruitment of species that traditionally inhabit tidal freshwater areas in other parts of the estuary will increase.

The members of Oligochaeta Naidinae, which increased in density at impacted sites in the rainy season, are usually recorded in freshwater environments (Learner et al. 1978). Naidinae are excellent swimmers and are capable of dispersing rapidly (Cellot and Juget 1998). Therefore, this group may have taken advantage of the increased fluvial flow and lowered salinity in the rainy season to increase their distribution at impacted sites with sediments containing more sand, where they achieve greater abundance, and where there are fewer polychaetes.

Although the data indicate that environmental contamination has not resulted in a highly polluted environment with a significant reduction in fauna, the urban effluents have contributed to changing the distribution of organisms and increasing their spatial and temporal variability, which serves as a warning of future harmful effects on the biota.

\section{ACKNOWLEDGEMENTS}

We thank Dr. Paulo da Cunha Lana and Dr. Valérie Sarpedonti for valuable comments on earlier versions of the manuscript. Financial support was provided by the National Council for Scientific and Technological Development (CNPq-Brazil) (Grant CT Hidro 504308/2003-3). The first and third authors were benefited by scholarships from the National Council for Scientific and Technological Development (CNPq-Brazil).

\section{REFERENCES}

APHA - American Public Health Association. 1992. Standard methods for the examination of water and wastewater. American Public Health Association, Washington, $186 \mathrm{pp}$

Bemvenuti C.E. 1994. O poliqueta Nephtys fluviatilis Monro, 1937, como predador da infauna na comunidade de fundos moles. Atlântica 16: 87-98.

Bemvenuti C.E., Rosa-Filho J.S., Elliott M. 2003. Changes in softbottom macrobenthic assemblages after a sulphuric acid spill in the Rio Grande harbor (RS, Brazil). Braz. J. Biol. 63: 183-194.

Caspers H. 1971. The relationship of saprobial conditions to massive population of tubificids. In: Brinkhurst R.O., Cook D. G. (eds.), Aquatic Oligochaete Biology, Plenum Press, pp. 501-505.

Cellot B., Juget J. 1998. Oligochaete drift in a large river (French Upper Rhone): the effect of life cycle and discharge. Hydrobiologia 389: 183-191.

CETESB - Companhia de Tecnologia de Saneamento Ambiental do Estado de São Paulo. 1977. Técnicas de abastecimento e tratamento de água. CETESB, São Paulo, 287 pp.

Clark R.B. 2002. Marine Pollution. Oxford University Press, Oxford, $161 \mathrm{pp}$

Clarke K.R., Warwick R.M. 1994. Changes in marine communities: an approach to statistical analysis and interpretation. Plymouth Marine Laboratory, Plymouth, $144 \mathrm{pp}$.

Corrêa J.A.M., Pereira K.R. 2002. Estudo da dispersão de metais pesados em sedimentos da orla de Belém-PA. Bol. Mus. Para. Emílio Goeldi Sér. Ciências da Terra 14: 79-101.

Danovaro R., Dinet A., Duineveld G., Tselepides A. 1999. Benthic response to particulate fluxes in different trophic environments: a comparison between the Gulf of Lions-Catalan Sea (WMediterranean) and the Cretan Sea (E-Mediterranean). Prog. Oceanogr. 44: 287-312.

De Paula J.H.C, Rosa Filho J.S., Souza A.L.B., Aviz D.S. 2006. A meiofauna como indicadora de impactos da carcinicultura no estuário de Curuça (PA). Bol. Lab. Hidrobiol. 19: 61-72.

Elías R., Rivero M.S., Vallarino E.A. 2003. Sewage impact on the composition and distribution of polychaetes associated to intertidal mussel beds of the Mar del Plata rocky shore (Argentina). Iheringia 93: 309-318.

Elías R., Palacios J.R., Rivero M.S., Vallarino E.A. 2005. Shortterm responses to sewage discharge and storms of subtidal sand-bottom macrozoobenthic assemblages off Mar del Plata city, Argentina (SW Atlantic). J. Sea Res. 53: 231-242.

Ferrando A., Mendez N. 2011. Effects of organic pollution in the distribution of annelid communities in the Estero de Urías coastal lagoon, Mexico. Sci. Mar. 75: 351-358.

Flint R.W.J., Younk A. 1983. Estuarine benthos: Long-term community structure variations, Corpus Christi Bay, Texas. Estuaries 6: 126-141.

Giere O., Pfannkuche O. 1982. Biology and ecology of marine Oligochaeta. A review. Oceanogr. Mar. Biol. Annu. Rev. 20: 173-308.

Gray J.S. 1981. The ecology of marine sediments. Cambridge University Press, London, $185 \mathrm{pp}$.

Grizzle R.E., Penniman C.A. 1991. Effects of organic enrichment on estuarine macrofaunal benthos: a comparison of sediment profile imaging and traditional methods. Mar. Ecol. Prog. Ser. 74: 249-262.

Henrichs S.M. 1992. Early diagenesis of organic matter in marine sediments: progress and perplexity. Mar. Chem. 39: 119-149.

Holte B., Oug E. 1996. Soft-bottom macrofauna and responses to organic enrichment in the subarctic waters of Tromsq, Northern Norway. J. Sea Res. 36: 227-237.

IBGE - Instituto Brasileiro de Geografia e Estatística. 2008. Pesquisa Nacional de Saneamento Básico. Brasil, Brasília. (http:// www.ibge.gov.br/home/estatistica/populacao/ condicaodevida/ pnsb2008/default.shtm)

IBGE - Instituto Brasileiro de Geografia e Estatística. 2010. Censo populacional. Brasil, Brasília. (http://www.ibge.gov.br/cidadesat/topwindow.htm?1).

Kennish M.J. 1997. Practical handbook of estuarine and marine pollution. Boca CRC Press LLC, Florida, $254 \mathrm{pp}$.

Kimmerer W.J. 2002. Physical, biological, and management responses to variable freshwater flow into the San Francisco estuary. Estuaries 25: 1275-1290.

Kinne O. 1971. Salinity. In: Kinne O. (ed.), Marine Ecology. A comprehensive, integrated treatise on life in oceans and coastal waters. John Wiley and Sons, pp. 683-1244.

Learner M.A, Lochhead G., Hughes B.D. 1978. A review of the biology of the British Naididae (Oligochaeta) with emphasis on the lotic environment. Freshw. Biol. 8: 357-375.

Lima W.N., Santos M.T.P. 2001. Avaliação geoquímica ambiental de águas residuárias e de matéria orgânica degradada de canais de drenagem urbana (Belém-PA). Bol. Mus. Para. Emílio Goeldi Sér. Ciências da Terra 13: 3-40.

Mayer-Pinto M., Junqueira A.O.R. 2003. Effects of organic pollution on the initial development of fouling communities in a tropical bay, Brazil. Mar. Pollut. Bull. 46: 1495-1503.

McCann L.D., Levin L.A. 1989. Oligochaete influence on settlement, growth and reproduction in a surface-deposit-feeding polychaete. J. Exp. Mar. Biol. Ecol. 131:233-253.

McLusky D. S., Teare M., Phizacklea P. 1980. Effects of domestic and industrial pollution on distribution and abundance of aquatic oligochaetes in the Forth estuary. Helgol. Meeresunters. 33: $384-392$.

Méndez N. 2002. Annelid assemblages in soft bottoms subjected to human impact in the Urías estuary (Sinaloa, Mexico). Oceanol. Acta 25: 139-147.

Montagna P.A., Kalke R.D. 1992. The effect of freshwater inflow on meiofaunal and macrofaunal populations in the Guadalupe 
and Nueces Estuaries, Texas. Estuaries 15: 307-326.

Montagna P.A., Yoon W.B. 1991. The effect of freshwater inflow on meiofaunal consumption of sediment bacteria in microphytobenthos in San Antonio Bay, Texas, U.S.A. Est. Coast. Shelf Sci. 33: 529-547.

Moraes B.C., Costa J.M.N, Costa A.C.L., Costa M.H. 2005. Variação espacial e temporal da precipitação no Estado do Pará. Acta Amazon. 35: 207-214.

Nittrouer C.A., Demaster D.J. 1996. Oceanography of the Amazon continental shelf. Cont. Shelf Res. 16: 553-573.

Pagliosa P.R., Barbosa F.A.R. 2006. Assessing the environmentbenthic fauna coupling in protected and urban areas of southern Brazil. Biol. Conserv. 129: 408-417.

Pearson T.H., Rosenberg R. 1978. Macrobenthic succession in relation to organic enrichment and pollution of the marine environment. Oceanogr. Mar. Biol. Annu. Rev. 16: 229-311.

Pinheiro R.V.L. 1987. Estudo hidrodinâmico e sedimentológico do estuário Guajará-Belém (PA). Universidade Federal do Pará, Belém, 164 pp.

Ramos J.F.F. 2004. Poluição e contaminação da Orla de Belém-PA In: Uhly S., Souza E. L. (eds.), A questão da água na grande Belém. Casa de Estudos Germânicos da UFPA, pp. 121-148.

Reish D.J. 1980. Effect of domestic wastes on the benthic marine communities of Southern California. Helgol. Meeresunters. 33: 377-383.

Riley J.P. 1958. The rapid analysis of silicate rocks and minerals. Anal. Chim. Acta 19: 413-428.

Rosenberg D.M., Resh V.H. 1993. Freshwater biomonitoring and benthic macroinvertebrates. Chapman \& Hall, London, 488 pp.

Santos C.S.G., Lana P.C. 2001. Nereididae (Annelida, Polychaeta) da costa nordeste do Brasil. Gêneros Namalycastis, Ceratocephales, Laeonereis e Rutillienereis. Iheringia Sér. Zool. 91: 137-149.
Sardá R., Foreman K.H., Valiela I. 1992. Controls of benthic invertebrate populations and production of salt marsh tidal creeks: experimental enrichment and short- and long-term effects. In: Colombo G., Ferrari I., Ceccherelli V.U., Rossi R. (eds.), Marine eutrophication and population dynamics. Olssen and Olssen, pp. 85-91.

Sardá R., Valiela I., Foreman K. 1996. Decadal shifts in macrobenthic community structure and production in response to sustained long-term salt marsh experimental enrichment. J. Exp. Mar. Biol. Ecol. 205: 63-81.

Suguio K. 1973. Introdução à sedimentologia. EDUSP, São Paulo, $317 \mathrm{pp}$.

Venturini N., Muniz P., Bícego M.C., Martins C.C., Tommasi L.R. 2008. Petroleum contamination impact on macrobenthic communities under the influence of an oil refinery: integrating chemical and biological multivariate data. Est. Coast. Shelf Sci. 78: 457-467.

Walkley A., Black I.A. 1934. An examination of the Degtjareff method for determining soil organic matter, and a proposed modification of the chromic acid titration method. Soil Sci. 37: 29-38.

Warwick R.M. 2001. Evidence for the effects of metal contamination on the intertidal macrobenthic assemblages of the Fal Estuary. Mar. Pollut. Bull. 42: 145-148.

Ysebaert T., Fettweis M., Meire P., Sas M. 2005. Benthic variability in intertidal soft-sediments in the mesohaline part of the Schelde estuary. Hydrobiologia 540: 197-216.

Scient ed.: R. Sardá.

Received December 9, 2010. Accepted November 2, 2011.

Published online February 16, 2012. 